\title{
Effect of an alcoholic diet on dental caries and on Streptococcus of the mutans group. Study in rats
}

\author{
Efeito de uma dieta alcoólica sobre cárie \\ dentária e sobre estreptococos do grupo \\ mutans. Estudo em ratos
}

\begin{abstract}
Karla Zanini Kantorski(a)
Daniela Martins de Souza(a) Verônica Quispe Yujra ${ }^{(b)}$

Juliana Campos Junqueira(c) Antonio Olavo Cardoso Jorge ${ }^{(d)}$ Rosilene Fernandes da Rocha ${ }^{(c)}$
\end{abstract}

(a) Doctoral Students in Oral Biopathology; (b) Undergraduate Dental Student; (c) PhDs, Professors, Department of Bioscience and Oral Diagnosis; (d)Full Professor, Department of Bioscience and Oral Diagnosis - School of Dentistry of São José dos Campos, São Paulo State University.

Corresponding author:

Karla Zanini Kantorski

Rua Vale Machado, 1351, ap. 301

Santa Maria - RS - Brazil

CEP: $97010-530$

E-mail:kzkantorski@terra.com.br

Received for publication on Nov 30, 2005 Sent for alterations on Sep 13, 2006

Accepted for publication on Nov 27, 2006

\begin{abstract}
The objective of this study was to evaluate the effects of an alcohol diet on Streptococcus of the mutans group and on dental caries in the oral cavity of rats. Forty animals were divided into 3 groups according to the following liquid diets: $20 \%$ ethanol solution (Alcohol Group, AG), 27\% sucrose solution (Isocaloric Group, IG), and water (Control Group, CG). After 56 days, samples were collected and plated on Mitis Salivarius Bacitracin agar to assess the number of colony forming units (CFU/mL) of Streptococcus of the mutans group. The animals were sacrificed and the jaws were removed in order to assess the occurrence of dental caries on the smooth and occlusal surfaces using stereomicroscopy. The data were submitted to ANOVA and Tukey test. The average numbers of CFU/mL $\left(10^{3}\right)$ were: 8.17 (AG), 9.78 (IG), and 5.63 (CG). There was no significant difference among the groups for the occurrence of occlusal caries. Regarding smooth surface caries, in the upper jaw, the caries number in the IG (1.58) was similar to that in the AG (2.06) and in the CG (1.14), and the number of caries in the AG was higher than in the CG; in the lower jaw there was significant difference among the 3 groups: AG (1.14), IG (2.00) and CG (0.43). The diets with the alcohol and sucrose solutions presented a tendency of increasing the colonization by Streptococcus of the mutans group and of increasing the occurrence of smooth surface dental caries in rat molars when compared to the control diet.
\end{abstract}

Descriptors: Ethanol; Streptococcus mutans; Dental caries; Alcoholism.

Resumo: O presente estudo avaliou o efeito de uma dieta alcoólica sobre estreptococos do grupo mutans e sobre cárie dentária na cavidade bucal de ratos. Quarenta animais foram divididos em 3 grupos conforme a dieta líquida administrada: solução de etanol a $20 \%$ (Grupo álcool, GA), solução de sacarose a 27\% (Grupo isocalórico, GI) e água (Grupo controle, GC). Após 56 dias, amostras bucais foram coletadas e semeadas em ágar Mitis Salivarius Bacitracina para contagem de unidades formadoras de colônias (UFC/mL) de estreptococos do grupo mutans. Os animais foram sacrificados, maxila e mandíbula foram removidas para analisar a ocorrência de cárie nas faces livres e oclusais usando lupa estereoscópica. Os dados foram submetidos à ANOVA e ao teste de Tukey. As médias dos números de UFC/mL (10³) foram: 8,17 (GA), 9,78 (GI), e 5,63 (GC). Não houve diferença significativa entre os grupos para a ocorrência de cárie oclusal. Em relação ao número de cáries em face livre, na maxila este número no GI $(1,58)$ foi similar ao encontrado no GA $(2,06)$ e no GC $(1,14)$, e o número de cáries no GA foi maior do que no GC; na mandíbula houve diferença significante entre os três grupos: GA $(1,14)$, GI $(2,00)$ e GC $(0,43)$. A dieta com soluções de álcool e sacarose apresentou tendência de aumento na colonização de estreptococos do grupo mutans e aumentou a incidência de lesões de cárie de faces livres nos molares de ratos quando comparada à dieta controle.

Descritores: Etanol; Streptococcus mutans; Cárie dentária; Alcoolismo. 


\section{Introduction}

Alcohol abuse and addiction have become a public health problem in occidental societies, surpassed only by cardiopathies and cancer. ${ }^{18}$ Severe alcoholism conditions have been associated with improper care of oral health and consequent changes in oral tissues. ${ }^{1,5,17}$ Literature reports association between alcoholism and gingival inflammation, alterations on the tongue, pigmentation on the mucosa, probability of severe periodontal disease and greater risk of oral cancer. ${ }^{8,21,22}$

There are some differences in the results of the studies which evaluate the occurrence of caries in alcoholic individuals. ${ }^{5,17}$ These variations are due to some factors such as duration and type of alcohol abuse, oral hygiene, smoking habit, time since the last visit to the dentist, sugar consumption, occurrence of abnormal hepatic function and therapy with lactulose. ${ }^{17}$

The complexity of the bacteria-diet-host interaction leads to the use of animal models by researchers, where caries lesions can be studied under controlled conditions. Rats and hamsters developed caries when fed with a cariogenic diet and began to be used by their availability and cost in spite of the differences between the anatomical structures of humans and rodents. ${ }^{10,12}$

The importance of Streptococcus of the mutans group in the development of caries has been emphasized. ${ }^{23,24}$ Studies on oral microbiota have shown a high number of these microorganisms in biofilm and saliva, and this can predispose to a significant increase in caries activity. ${ }^{7,23}$ Therefore, the purpose of this study was to evaluate the presence and distribution of caries lesions and changes in the quantity of Streptococcus of the mutans group in the oral cavity of rats submitted to an alcoholic diet.

\section{Material and Methods}

Forty Wistar rats (Rattus norvegicus albinus) (120 days of age, weighing an average of $250 \mathrm{~g}$ ) were used. The animals were kept in cages ( 3 animals per cage) at room temperature. This work was approved by the Research Ethics Committee, School of Dentistry of São José dos Campos, São Paulo State University (UNESP).
The animals were randomly divided into 3 groups according to the type of liquid diet administered:

- Control group (CG, $n=10)$ : water;

- Alcohol group (AG, $n=15$ ): 20\% alcoholic solution $(\mathrm{v} / \mathrm{v})$;

- Isocaloric group (IG, $\mathrm{n}=15$ ): $27 \%$ sucrose solution.

All groups received a solid diet of Nutrilabor pet food (Guabi, Campinas, SP, Brazil). The IG received a diet with the same caloric value consumed by the AG. Daily, the quantity of food and alcohol solution consumed by the AG was controlled. On the following day, the same values were administered to the IG.

Initially, the AG went through an adaptation period (4 days: $5 \%$ alcoholic solution, 4 days: $10 \%$ alcoholic solution, 4 days: $15 \%$ alcoholic solution). After that, a $20 \%$ alcoholic solution was administered $(\mathrm{v} / \mathrm{v})$ for 56 days.

\section{Microbiologic analysis}

After 56 days, the animals were anesthetized and samples were collected from the oral cavity for 60 seconds with a swab. The swab was inserted in a test tube with $0.95 \mathrm{ml}$ of sterilized physiological solution. Decimal dilutions up to $10^{4}$ were carried out, and $0.1 \mathrm{ml}$ was plated in duplicate on Mitis Salivarius Bacitracin agar (Difco Laboratories, Detroit, Mich., USA) with $20 \%$ sucrose. The plates were incubated at $37^{\circ} \mathrm{C}$ and under $5 \% \mathrm{CO}_{2}$ for 48 hours.

After incubation, the plates with 30 to 300 typical colonies of Streptococcus of the mutans group were counted in a colony counter (Phoenix CP-600, Araraquara, SP, Brazil), and mean values of colony forming units were obtained (CFU/mL). Mean values of CFU/mL were converted into logarithmic values for statistical analysis.

\section{Dental caries analysis}

After samples were collected from the oral cavity, the animals were decapitated. Their mandible and maxilla were removed, dissected and fixed in formol in order to assess the presence of caries lesions in the upper and lower molars of the right side of each animal.

For the evaluation of occlusal caries, the maxillae were fixed in utility wax in order to place the molar 
occlusal surfaces on the same plane. The specimens were visualized with a stereoscopic loupe $(15 \mathrm{X})$ and photographed with a digital camera mounted to the appliance. The images were loaded in the Image $\mathrm{J}$ 1.31p program (bttp://rsb.info.nih.gov/), and a grid was placed over them. The grid intersection points that overlay the areas with caries were marked. Thus, the extent of the caries lesions on the occlusal surfaces was evaluated. The number of occlusal caries was not evaluated because it was similar among the groups.

To evaluate smooth surfaces caries, the maxillae were fixed in utility wax with the smooth surfaces placed parallel to the wax. They were then observed with a stereoscopic loupe $(15 \mathrm{X})$. The number of caries lesions was evaluated. Smooth surfaces caries were considered as lesions that did not extend to the occlusal surface.

\section{Statistical analysis}

The data obtained as $\log \mathrm{CFU} / \mathrm{mL}$ values, number of grid intersection points over lesions of occlusal caries, and number of smooth surface caries were submitted to analysis of variance and Tukey test using the MINITAB software for Windows, version 13.1 (2000, Minitab Inc., State College, PA, USA), at a $5 \%$ significance level.

\section{Results}

Animals from the CG consumed an average of 51.21 daily calories (kcal/day) from the solid diet. Animals from the AG and IG presented an average consumption of $51.72 \mathrm{kcal} / \mathrm{day}$. Of these, 20.59 $\mathrm{kcal} /$ day came from the liquid diet, which corresponded to $40.10 \%$ of the total diet calories. The animals from the CG gained weight, and those from the AG and IG lost weight, during the experimental period.

The mean values of CFU/mL $\left(10^{3}\right)$ of Streptococcus of the mutans group were $5.63 \pm 4.33$ for the CG, $8.17 \pm 6.69$ for the AG and $9.78 \pm 4.38$ for the IG. There was no statistically significant difference among the groups $(p=0.2605)$.

In relation to occlusal caries lesions, no difference was observed among the groups for the maxilla $(p=0.694)$, for the mandible $(p=0.502)$, and for
Table 1 - Mean values and standard deviations for smooth surface caries lesions.

\begin{tabular}{l|c|c|c}
\hline \multicolumn{1}{c|}{ Groups } & Maxilla & Mandible & $\begin{array}{c}\text { Maxilla and } \\
\text { Mandible }\end{array}$ \\
\hline Control (CG) & $1.14 \pm 0.86 \mathrm{a}^{* *}$ & $0.43 \pm 0.52 \mathrm{a}$ & $0.78 \pm 0.79 \mathrm{a}$ \\
\hline Alcohol (AG) & $2.06 \pm 1.12 \mathrm{~b}$ & $1.14 \pm 0.86 \mathrm{~b}$ & $1.63 \pm 1.10 \mathrm{~b}$ \\
\hline Isocaloric (IG) & $1.58 \pm 0.90 \mathrm{ab}$ & $2.00 \pm 0.97 \mathrm{c}$ & $1.87 \pm 0.94 \mathrm{~b}$ \\
\hline Value of $\mathrm{p}^{*}$ & 0.008 & 0.000 & 0.002 \\
\hline
\end{tabular}

the association of both maxilla and mandible together $(p=0.560)$.

In relation to smooth surface caries lesions in the maxilla, it was observed that the IG value was similar to that for the AG and to that for the CG; however, the AG presented a higher number of lesions than did the CG. In the mandible, the IG presented a higher number of lesions than did the AG, which presented a higher number than did the CG. Considering both the mandible and the maxilla, no difference was observed between the IG and AG values, and the values for the latter groups were significantly higher than that for the CG (Table 1).

The percentage of molars with occlusal and smooth surface caries lesions was $95 \%$ and $47.6 \%$ for the CG, $98.8 \%$ and $82.2 \%$ for the $A G$, and $100 \%$ and $91.1 \%$ for the IG, respectively.

\section{Discussion}

Variations in the occurrence of caries were observed in studies with animals. These variations seem to be related to environmental changes, such as the type of microbiota that the animals are exposed to in the first hours of life. ${ }^{9}$ In the present study, the rats were born and kept under the same conditions.

The association between alcohol and caries has been investigated. Epidemiological studies observed a greater incidence of caries and tooth loss in alcoholic individuals. However, this has been attributed to improper hygiene and to social condition. ${ }^{1,3,5}$

The ingestion of alcohol can lead to nutritional deficiency, impairing the absorption of various substances. ${ }^{13}$ Thus, studies on the effect of alcohol on biological tissues require an isocaloric nutritional 
control group in order to establish if the observed changes are related to the effect of alcohol or to the nutritional deficiency generated by the alcoholic diet.

In the present study, weight loss was observed in the AG and IG, indicating nutritional alterations. In spite of having received a caloric diet, the IG lost weight probably due to a limited quantity of liquid and solid administered. Around 90 to $95 \%$ of the ingested alcohol is metabolized in the liver and the rest is excreted by the lungs, kidneys and through sweat. During excretion, most of the alcohol is oxidized. This oxidation generates energy and each gram of alcohol is converted into $7.1 \mathrm{kcal}$. In alcoholic individuals, around $60 \%$ of their daily calories come from alcohol, which are not associated to proteins, minerals or vitamins, and are not used biochemically. ${ }^{13,18}$

Although the statistical analysis did not reveal any significant differences among the groups for $\mathrm{CFU} / \mathrm{mL}$, increasing values were observed respectively for the CG, AG and IG. The rats of the CG received only laboratory pet food and presented $5.63 \times$ $10^{3} \mathrm{CFU} / \mathrm{mL}$ of Streptococcus of the mutans group. Jorge et al. ${ }^{7}$ (1991) also found $S$. mutans in the oral cavity of rats fed with pet food. However, Isogai et al. ${ }^{6}$ (1985) isolated this microorganism only in the gingival sulcus and in low proportions, but more than 15 different bacterial species of Streptococcus spp., Lactobacillus spp., Veilonella spp. and Neisseria spp. were found in the saliva, tongue, oral mucosa and gingival sulcus.

The IG presented a higher number of $\mathrm{CFU} / \mathrm{mL}$ of Streptococcus of the mutans group than did the GC. These data corroborate the data found in literature, which shows increased counts of this microorganism and of Lactobacillus in the oral cavity of individuals and animals that eat a sucrose-rich diet., ${ }^{75,16}$ The fermentation of sucrose into lactic acid results in a decrease in $\mathrm{pH}$, favoring the growth of acidogenic and aciduric bacteria. ${ }^{12}$ Administration of a sucrose solution for 56 days resulted in a count of $9.78 \times 10^{3}$ CFU/mL of Streptococcus of the mutans group for the IG rats. However, Jorge et al. ${ }^{7}$ (1991) found a higher mean value in rats treated with a cariogenic diet $(56 \%$ sucrose, $28 \%$ ground pet food and $16 \%$ powdered milk) for 60 days. The difference in the results may be attributed to diet consistency, since sticky food seems to be more cariogenic because of their longer contact with the teeth and saliva. ${ }^{11}$ Jorge et al. ${ }^{7}$ (1991) also introduced the cariogenic diet right after the weaning of the animals, which may have influenced the early establishment of a cariogenic microbiota.

The count of Streptococcus of the mutans group for the AG was also higher than that for the CG. The consumption of alcohol leads to a decrease in salivary flow, which favors the growth of cariogenic bacteria. ${ }^{20}$ Saliva is important in the mechanical removal of microorganisms and food, in keeping the $\mathrm{pH}$ and in the elimination of bacteria through the action of immunoglobulines and enzymes. ${ }^{2,25}$ Moreover, the acetaldehyde rate (derivate of alcohol metabolism in the oral cavity) may alter the quality of the microbiota. High concentrations of acetaldehyde seem to cause an increase in aerobic Gram-positive bacteria, such as $S$. salivarius, Corynebacterium spp., Stomatococcus spp., but do not seem to interfere in the number of $S$. mutans. ${ }^{4}$ In the present study, higher mean values of Streptococcus of the mutans group occurred with the consumption of alcohol. It is suggested that further researches investigate the relationship between acetaldehyde rate and the count of these microorganisms.

Regardless of the diet, a high incidence of occlusal caries was observed. The occlusal surface presents developed retentive areas. Caries lesions of pits and fissures result from the retention of food and bacteria by impaction; and smooth surface lesions depend more on the microorganisms' adhesiveness. ${ }^{14}$ These data corroborate the data presented by Pinheiro et al. ${ }^{19}$ (2002), who found enamel caries on the occlusal surface in $72.5 \%$ of molars of rats that received a cariogenic diet, and in $89.2 \%$ of molars of animals treated with laboratorial pet food. The number of smooth surface caries was statistically higher in the IG than in the GC. Sucrose has been reported to be the fundamental substrate for the synthesis of extracellular glucan, which is the main component of the structural matrix of dental biofilm, and is responsible for the ability of Streptococci of the mutans group to accumulate on the smooth surface of teeth. ${ }^{26}$ 
In the present study, rats treated with an alcoholic diet presented a higher number of smooth surface caries than the control group, and the count of Streptococcus of the mutans group was also higher, although not statistically significant, which suggests that alcohol directly affects the microbiota and oral tissues.

\section{References}

1. Enberg N, Wolf J, Ainamo A, Alho H, Heinala P, LenanderLumikari M. Dental diseases and loss of teeth in a group of Finnish alcoholics: a radiological study. Acta Odontol Scand. 2001;59(6):341-7.

2. Guggenheimer J, Moore PA. Xerostomia etiology, recognition and treatment. J Am Dent Assoc. 2003;34(1):61-9.

3. Hede B. Determinants of oral health in a group of Danish alcoholics. Eur J Oral Sci. 1996;104(4):403-8.

4. Homann N, Tillonen J, Meurman JH, Rintamäki H, Lindqvist $\mathrm{C}$, Rautio $\mathrm{M}$ et al. Increased salivary acetaldehyde levels in heavy drinkers and smokers: a microbiological approach to oral cavity cancer. Carcinogenesis. 2000;21(4):663-8.

5. Hornecker E, Muuss T, Ehrenreich H, Mausberg RF. A pilot study on the oral conditions of severely alcohol addicted persons. J Contemp Dent Pract. 2003;4(2):51-9.

6. Isogai E, Isogai H, Sawada H, Kaneko H, Ito N. Microbial ecology of plaque in rats with naturally occurring gingivitis. Infect Immun. 1985;48(2):520-7.

7. Jorge AOC, Almeida NQ, Fantinato V, Shimizu MT. Adsorção de Streptococcus mutans pela cenoura - observações experimentais em ratos. Rev Odontol UNESP. 1991;20(1):67-74.

8. Larato DC. Oral tissue changes in the chronic alcoholic. J Periodontol. 1972;43(12):772-3.

9. Larson RH, Zipkin I. Influence of early environment of newborn rats on development of dental caries. Arch Oral Biol. 1965;10:23-7.

10. Loesche WJ. Modelo animal de cárie dentária. In: Loesche WJ. Cárie dental: uma infecção tratável. Rio de Janeiro: Cultura Médica; 1993. Cap. 8. p. 82-102.

11. Lorenzo JL. Microbiologia para o estudante de Odontologia. São Paulo: Atheneu; 2004.

12. Marcotte H, Lavoie MC. Oral microbial ecology and the role of salivary immunoglobulin A. Microbiol Mol Biol Rev. 1998;62(1):71-109.

13. Masur J. Farmacologia do álcool etílico. In: Valle LBS, Oliveira-Filho RM, DeLucia R, Oga S. Farmacologia Integrada. VII Fundamentos farmacológicos da terapêutica. Rio de Janeiro: Atheneu; 1991. Cap. 9. p. 109-17.

\section{Conclusion}

Diets with an alcohol solution and a sucrose solution tended to increase the colonization by Streptococcus of the mutans group and increase the incidence of smooth surface caries lesions on molars of rats when compared to a control diet.

14. Menaker L. Cáries dentárias: bases biológicas. Rio de Janeiro: Guanabara Koogan; 1984.

15. Minah GE, Solomon ES, Chu K. The association between dietary sucrose consumption and microbial population shifts at six oral sites in man. Arch Oral Biol. 1985;30(5):397-401.

16. Navia JM, Lopez H. Sources of variability in rat caries studies: weaning age and diet fed during tooth eruption. J Dent Res. 1977;56(3):222-7.

17. Novacek G, Plachetzky U, Pötzi R, Lentner S, Slavicek R, Gangl A et al. Dental and periodontal disease in patients with cirrhosis - role of etiology of liver disease. J Hepatol. 1995;22(5):576-82.

18. Pereira ELA, Sena EP, Oliveira IR. Farmacologia do álcool etílico. Tratamento farmacológico do alcoolismo. In: Silva P. Farmacologia. $6^{\text {a }}$ ed. Rio de Janeiro: Guanabara Koogan; 2002. Cap. 38. p. 351-7.

19. Pinheiro JT, Couto GB, Vasconcelos MM, Melo MM, Guedes RC, Cordeiro MA. Effect of a Brazilian regional basic diet on the prevalence of caries in rats. Braz J Med Biol Res. 2002;35(7):823-6.

20. Riedel F, Goessler U, Hormann K. Alcohol-related diseases of the mouth and throat. Best Pract Res Clin Gastroenterol. 2003;17(4):543-55.

21. Tezal M, Grossi SG, Ho AW, Genco RJ. Alcohol consumption and periodontal disease. The Third National Health and Nutrition Examination Survey. J Clin Periodontol. 2004;31(7):484-8.

22. Tezal M, Grossi SG, Ho AW, Genco RJ. The effect of alcohol consumption on periodontal disease. J Periodontol. 2001;72(2):183-9.

23. Van Houte J. Bacterial specificity in the etiology of dental caries. Int Dent J. 1980;30(4):305-26.

24. Van Houte J, Gibbs G, Butera C. Oral flora of children with “nursing bottle caries". J Dent Res. 1982;61(2):382-5.

25. Van Nieuw Amerongen A, Bolscher JG, Veerman EC. Salivary proteins: protective and diagnostic value in cariology? Caries Res. 2004; 38(3):247-53.

26. Zero DT. Sugars - The arch criminal? Caries Res. 2004; 38(3):277-85. 